Copyright (C) 2020 University of Bucharest

Printed in Romania. All rights reserved

ISSN print: $1224-5984$

ISSN online: $2248-3942$
Rom Biotechnol Lett. 2020; 25(1): 1267-1274

doi: $10.25083 / \mathrm{rbl} / 25.1 / 1267.1274$

Received for publication, July, 26, 2018

Accepted, December, 7, 2018

Original paper

\title{
The involvement of oxidative stress in Chronic Myeloid Leukemia
}

\author{
EMILIA GEORGIANA PASCU ${ }^{*}$, MIHNEA-ALEXANDRU GĂMAN ${ }^{2}$, CORNEL MOISĂ $\breve{3}^{3}$, \\ ALEXANDRU DAN ASSANI ${ }^{1}$, AMELIA MARIA GĂMAN ${ }^{1,4}$
}

\author{
${ }^{1}$ University of Medicine and Pharmacy of Craiova, Craiova, Romania \\ 2"Carol Davila" University of Medicine and Pharmacy, Bucharest, Romania \\ ${ }^{3}$ Department of Hematology, Emergency County Hospital Slatina, Slatina, Romania \\ ${ }^{4}$ Department of Hematology, Filantropia City Hospital, Craiova, Romania
}

\begin{abstract}
In the past decades, the involvement of reactive oxygen species (ROS) in health and disease has been intensely studied. Apart from their antimicrobial role in phagocytosis, ROS are also involved in a multitude of cellular processes, such as cell cycle progression, cellular motility or amplification of signaling factors. Many diseases are characterized by an overproduction of ROS or by deficient antioxidant systems, thus leading to oxidative stress (OxS) onset.

The involvement of $\mathrm{OxS}$ in several types of solid cancers (prostate cancer, breast cancer, colorectal cancer and melanoma) and hematological malignancies (acute lymphoblastic leukemia, myelodysplastic syndromes, acute and chronic myeloid leukemia) has been proved. Recent studies have hypothesized that ROS derived from tumors can promote cell survival, migration, metastasis, proliferation and even drug-resistance according to the origin of the cancer. However, the involvement of OxS in carcinogenesis is far from being completely understood.
\end{abstract}

Keywords Reactive oxygen species, antioxidant capacity, oxidative stress, tyrosine kinase inhibitors, chronic myelogenous leukemia.

To cite this article: PASCU EG, GĂMAN M-A, MOISĂ C, ASSANI AD, GĂMAN AM. The involvement of oxidative stress in Chronic Myeloid Leukemia. Rom Biotechnol Lett. 2020; 25(1): 1267-1274. DOI: $10.25083 / \mathrm{rbl} / 25.1 / 1267.1274$

*Corresponding author: EMILIA GEORGIANA PASCU, University of Medicine and Pharmacy of Craiova, Craiova, Romania E-mail: emilia_22apr@yahoo.com 


\section{Sources of ROS in normal hematopoietic cells}

ROS are a heterogeneous group of large reactivity spectrum molecules and free radicals derived from diatomic oxygen. In physiological systems, the formation of ROS starts with the univalent reduction of oxygen to produce superoxide radicals. ROS co-location at nitric oxide sites $(\mathrm{NO} \bullet$ ) can lead to the formation of a distinctive family of pro-oxidant molecules known as reactive nitrogen species (TRUONG \& al [1]).

- Mitochondrial ROS

The mitochondrial electron transport chain is a system of redox-coupled proteins in the inner mitochondrial membrane. At this point, high-level energy electrons donated by nicotinamide adenine dinucleotide (NAD) are used to form adenosine 5 triphosphate (ATP). The proximal enzyme in the electron transport chain is NADH dehydrogenase (complex I). This complex accepts high-level energy donated by NADH and is the most common ROS formation site in mitochondria (SHADEL \& al [2]).

- NADPH oxidases

NADPH oxidases (NOX) are a group of proteins which catalyze the univalent reduction of $\mathrm{O}_{2}$ to superoxide using NADPH as electron donor (MANEA \& al [3]). The first discovered member of this complex was NOX2. NOX2 has a major role in destroying pathogens in mature phagocytes. Afterwards, based on the observation that certain non-phagocytic cells can produce significant quantities of superoxide in spite of a deficit of NOX2, other seven members of the NOX group were discovered, i.e. NOX1-5 and double oxidase (DUOX) 1 and 2 (LAMBETH $\&$ al [4]). It seems that several members of the NOX complex and their regulatory proteins are synthesized and function in the cell membrane of the CD34+ hematopoietic progenitor cells (HOLE \& al [5]).

\section{ROS involvement in cellular signaling}

Several metabolic pathways are associated with ROS production, including polyamine metabolism, cytochrome P450 activity, and xanthine oxidase activity. It has been proven that the metabolism of arachidonic acid plays an important role in murine hematopoietic stem cells. It is also involved in the production of a significant quantity of intracellular ROS (KINDER \& al [6]).

Superoxide is mainly generated in hematopoietic cells. Its overproduction leads to the production of highly aggressive molecules, especially hydroxyl radicals that exhibit destructive effects on cells. Hydroxyl radicals can determine interchain breaks of the DNA or can react with guanine residues, thus forming 8-oxoguanine (SHOKOLENKO \& al [7]). The markers of lipid peroxidation are isoprostanes and malonyl dialdehyde. Also, carbonylated proteins are used to measure oxidative damage of proteins in hematological malignancies (MARROCCO \& al [8]).

If ROS are overproduced, more antioxidant enzymes are synthesized by almost all human cells (KURUTAS \& al [9]) and, also plant cells (STEF \& al [10]), in order to neutralize ROS and to operate in the key-points of ROS production networks. Superoxide dismutase (SOD) is the main enzyme responsible for eliminating ROS before it can partake in the synthesis of other ROS. It constitutes an important defense line against oxidative stress, being synthesized in the cytosol mitochondria, as well as in the extracellular space (LEI \& al [11]).

There are known several mechanisms that regulate $\mathrm{H}_{2} \mathrm{O}_{2}$ levels in eukaryote cells. The most frequent elements involved are catalase, glutathione and the peroxiredoxin system (ANU \& al [12]).

In appropriate quantities, ROS have positive effects on cell functions, acting as signaling molecules. Exogenous superoxide and $\mathrm{H}_{2} \mathrm{O}_{2}$ aid cell proliferation, e.g. multiplication of human fibroblasts or proliferation of amniotic cells (IKEBUCHI \& al [13]). Moreover, G-CSF (granulocyte colony stimulating factor) facilitates ROS production and cell cycle progression, whereas its blockade through ROS production suppresses proliferation and viability (ZHU \& al [14]). $\mathrm{H}_{2} \mathrm{O}_{2}$ might act as a secondary messenger, since it is involved in multiple processes such as: cell transformation, senescence, apoptosis, and extracellular matrix remodeling (SIES [15]).

\section{ROS and normal hematopoiesis}

ROS role in normal hematopoiesis is still debatable. Several studies on murine models and human hematopoietic cells suggest that ROS are necessary for primitive hematopoietic cells (ABDOUH \& al [16]). A recent hypothesis suggests that, in order to maintain $\mathrm{CSH}$ pools, the viral oncogene of the v-Akt murine thymoma uses the forkhead box-O (FOXO) transcription factors family as signaling molecules (YALCIN \& al [17]). It has also been proved that both normal human CD34+ cells and leukemia cells deficient for the BMI1 protein family exhibit longterm decreased replicative capacity, inferring that BMI1 plays a role in the self-renewal of $\mathrm{CSH}$ and progenitor cells (ABDOUH \& al [16]). It is relevant that the loss of self-renewal ability co-occurred with a reduced synthesis of FOXO3A and high intracellular ROS levels, while antioxidant treatment determined a partially reversible effect (JOSHI \& al [18])

A similar effect was observed in Atm-deficient mice that rapidly developed bone marrow deficiency via increased ROS levels and decreased viability of CSH and progenitor cells populations. The conditioned removal of all FOXO isoforms in mice resulted in quick bone marrow failure by means of $\mathrm{CSH}$ depletion (accelerated apoptosis and ROS increase). Antioxidant treatment was sufficient to alleviate this phenotype, which suggests that increased ROS levels were important factors in the loss of the selfrenewal ability (TOTHOVA \& al [19]). These studies imply that the overproduction or the excessive decrease of ROS levels lead to malfunctioning CSH. This sensitivity of $\mathrm{CSH}$ to increased levels of ROS may partially explain the observation that $\mathrm{CSH}$ aggregates tend to be located in the least hypoxic areas of the bone marrow (SUDA \& al [20]). 
Other CSH functions are influenced by ROS levels, for example the ROS-dependent synthesis of the vascular adhesion protein- 1 in the endothelial cells of the bone marrow. This is necessary for the initial stages of bone marrow niche development and in bone marrow transplantation (LEWANDOWSKI \& al [21]). ROS may be necessary for the migration of hematopoietic progenitor cells. Murine bone marrow cells deficient for NOX2 responded by chemotaxis, invasion and re-organization of actines to the interaction with the stromal cell-derived factor 1 . This phenotype was associated with a reduced activity of Akt phosphorylation (USHIO \& al [22]), while the treatment with antioxidants suppressed the response of these cells in mice treated with G-CSF (GOLAN \& al [23]).

\section{ROS production and the consequences of OxS in myeloid disease}

In chronic myeloid leukemia (CML), the expression of the BCR-ABL gene seems to induce ROS production in hematopoietic cells (KIM \& al [24]), while ROS are vital for the transformation induced by the BCR-ABL gene synthesis (RODRIGUES \& al [25]).

In patients with CML, an increased level of OxS was observed (quantified by means of oxidative stress markers such as malondialdehyde and carbonyl proteins) in comparison with healthy controls. OxS levels increased and the plasma antioxidants decreased as the disease evolved. Although the origin of ROS in patients with CML is still uncertain, nowadays it is considered that the source is represented by NOX4 activity and by the mitochondrial production (IRWIN \& al [26]). Regarding ROS and OxS involvement in acute myeloid leukemia (AML), increased levels of ROS and oxidative lesions of the DNA were found in a murine model of AML induced by a mutant expression of N-Ras and Bcl-2 genes (RASOOL \& al [27]). In human subjects, however, ROS production in AML patients was significantly increased vs. controls (ER \& al [28]).

A series of oncogenes like KRAS, cMYC, BCR/ABL, NRF2 and NF-kB can alter the RedOx balance in malignant cells, including leukemic cells (AMINA \& al [29]). In metabolic disorders, it seems that isocitrate dehydrogenase mutations (IDH1 or IDH2), frequent in AML, fostering the conversion of isocitrate to 2-hydroxyglutarate instead of alpha-ketoglutarate (WARD \& al [30]), generate an intracellular ROS increase.

$\mathrm{OxS}$ is also involved in the pathogenesis of chronic lymphocytic leukemia (CLL). In initial stages, an increase of ROS levels and a decrease of the antioxidant capacity were seen. Administration of antioxidants in these stages, through immune status improvement, seems to reduce the risk for infectious complications (GĂMAN \& al [31] [32]).

The consequences of the increased levels of ROS in myeloid leukemia may be classified into two major categories - the non-specific oxidation effects of biomolecules and specific effects resulted from the hyperactivation of ROS-dependent signaling pathways (UDENSI \& al [33]). Non-specific oxidative deterioration appears when increased levels of ROS persist and the antioxidant defense of the cell is surpassed. These conditions lead to lipid peroxidation, intracellular increase of $\mathrm{pH}$, and DNA damage either by means of direct chemical reactions or activation of carcinogens. This environment is highly susceptible to oncogenesis and it helps the selection of clones able to survive and grow. It has been proved that such a situation may lead to disease progression in AML; patients with the duplication tandem of FMS-like tyrosine kinase 3 (Flt3-ITD) show an increased production of ROS and an increased number of double-stranded DNA lesions. This can partially explain the bad prognosis of patients with Flt3-ITD mutations (STANICKA \& al [34]; SALLMYR \& al [35]).

In normal circumstances, most cells react to potential genotoxic stress by induction of cell cycle arrest and/or apoptosis in order to maintain genomic stability. This reaction is mediated by signaling pathways following stress activated protein kinases (SAPK); for example, c-Jun N-terminal kinase (JNK) and p38MAPK become phosphorylated as a result of genotoxic stress, and subsequently enable cell cycle arrest via members of the protein family INK4 and TP53. ROS such as $\mathrm{H}_{2} \mathrm{O}_{2}$ generated by malignant cells can offer a proliferative advantage to the malignant population, but they can also diffuse freely into neighbour cells, blocking their normal proliferation through a paracrine mechanism. If such an environment persists in the bone marrow, the $\mathrm{H}_{2} \mathrm{O}_{2}$ excess generated by malignant cells could disturb normal hematopoiesis. This aspect is supported by proofs according to which cells within the non-malignant population from patients with myeloid leukemia show signs of OxS (COBBAUT \& al [36]).

Increased ROS may have effects in myeloid malignancies through the abnormal change of signaling in ROS-dependent pathways, especially the pro-proliferation and/or pro-survival ones. In CML, the pro-proliferation expression of the Fyn molecule seems to depend on ROS induced by BCR-ABL (GAO \& al [37]). In studies regarding $\mathrm{AML}$, it has been proved that the expression of the fusion protein RUNX1-ETO in Drosophila melanogaster helps the proliferation of primitive hematopoietic cells in a ROS-dependent manner (SINENKO \& al [38]). Studies that have assessed the effect of IL-3 in the M07e human leukemia cell line showed that the proproliferative effect of this cytokine was mediated by the production of ROS through NOX2 activity. The survival advantage given by IL-3 was suppressed by NOX inhibitors or by the specific reduction of NOX2 expression (MARALDI \& al [39]).

OxS is involved in the onset of cognitive deficiencies in patients with cancer treated with doxorubicin, methotrexate and cyclophosphamide, alongside other risk factors. Chemotherapy generates ROS in these patients' plasma, enabling the oxidation of apolipoprotein A1 (ApoA1). This enhances the synthesis of TNF-alpha which penetrates the blood-brain barrier, enabling apoptosis and neuronal death (GĂMAN \& al [40]). A study carried out on children with ALL treated with specific chemotherapy revealed an association between the cognitive dysfunction generated by chemotherapy-induced $\mathrm{OxS}$ and the polymorphisms of 3 OxS genes (NOS 53894T, SLCO2A1 and GSTP1) (COLE \& al [41]). 


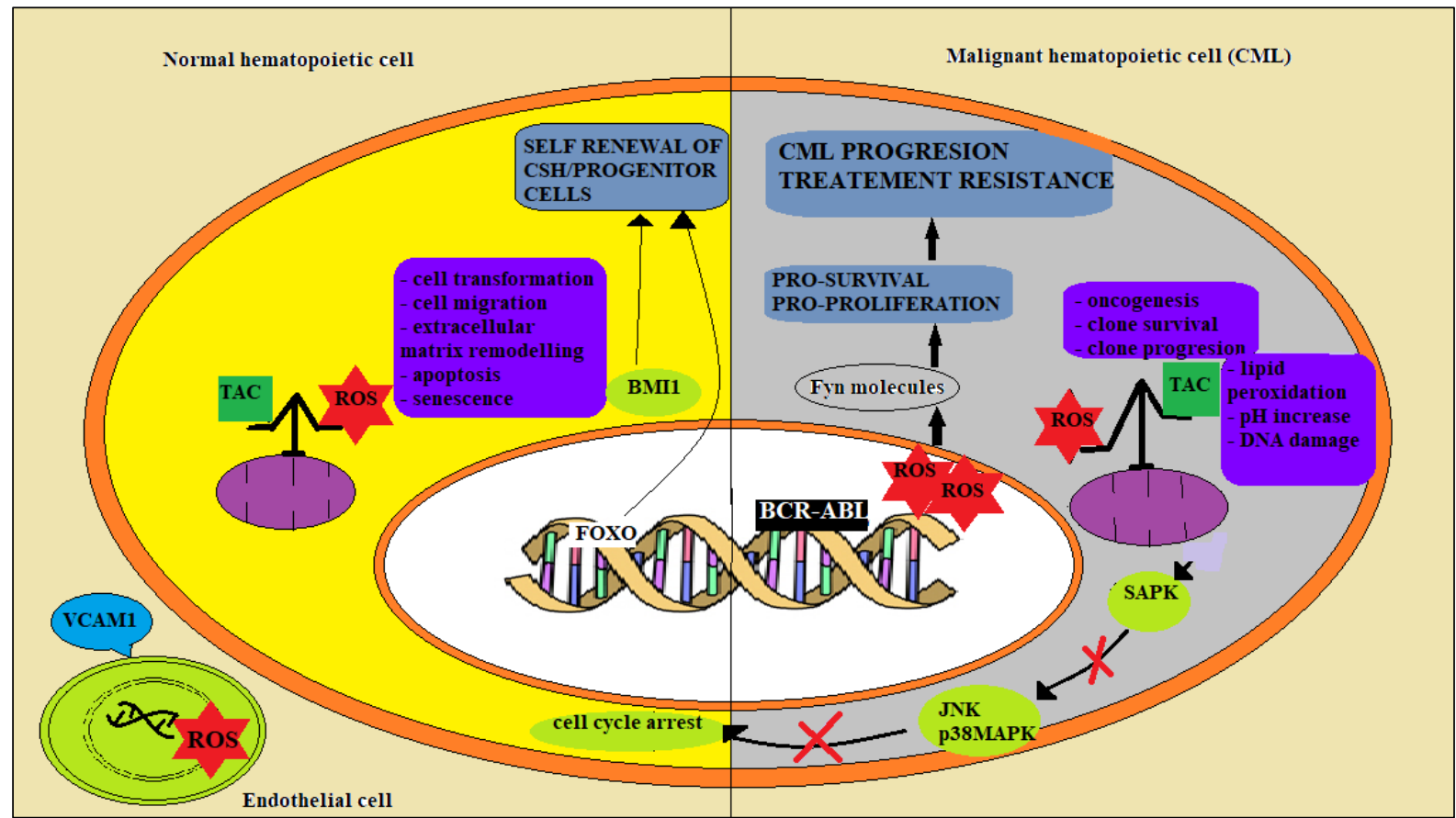

Figure 1. OxS in normal hematopoietic cell vs. malignant hematopoietic cell.

In normal haematopoietic cells, under the conditions of a balance between ROS and TAC, OxS is involved in multiple processes such as: cell transformation, cell migration, extracellular matrix remodeling, apoptosis, and senescence. It appears that FOXO transcription factors family and BMI1 protein family provide self-renewal of $\mathrm{CSH}$ and progenitor cells under a redox equilibrium. Also, synthesis of VCAM 1 in the endothelial cells of the BM is dependent on the level of ROS. In malignant hematopoietic cells, an increased level of OxS was observed (increased ROS production and decreased TAC). In CML, expression of the BCR-ABL gene appears to induce ROS production in malignant cells, while ROS are vital for the transformation induced by the BCR-ABL gene synthesis. OxS leads to lipid peroxidation, intracellular growth of $\mathrm{pH}$ and DNA damage, this environment being highly susceptible to oncogenesis and providing the selection of clones able to survive and grow. In normal circumstances, most cells react to genotoxic stress via cell cycle arrest in order to maintain genomic stability. This reaction is mediated by signaling pathways following SAPK; for example, JNK and p38MAPK become phosphorylated and enable cell cycle arrest. This pathway is blocked under the conditions of excessive OxS. In myeloid malignancies, increased ROS levels lead to extreme activation of pro-proliferation and / or pro-survival signaling pathways. In CML, the pro-proliferation expression of the Fyn molecule seems to depend on ROS induced by BCR-ABL. (ROS - reactive oxygen species, TAC - total antioxidant capacity, OxS - oxidative stress, VCAM 1 - vascular cell adhesion molecule $1, \mathrm{BM}$ - bone marrow, CML - chronic myeloid leukemia, SAPK - stress-activated protein kinases).

\section{The involvement of oxidative stress in CML pathogenesis and in the therapy with tyrosine kinase inhibitors}

Genomic instability is one of the characteristic features of cancer (DIACONU \& al [42]). It may also be responsible for the accumulation of mutations that generates malignant characteristics of the tumor cells, as well as the response to the specific therapy. The mechanisms and consequences of genomic instability may be significantly different in cancer stem cells (CSC) and in cancer progenitor cells (CPC). Genetic abnormalities in CSC may have no consequences if they occur in hibernating CSC. If CSC start dividing or the abnormalities induce proliferation or when genetic abnormalities occur in circulating CSC, they can generate resistance to therapy and/or the production of more malignant clones.

For decades, CML emerged as the very paradigm for understanding the multistep process of carcinogenesis, involving CSC and $\mathrm{CPC}$ that are responsible for the initiation and maintenance of the disease (MELO \& al [43]). CML is initiated by a BCR-ABL tyrosine kinase that transforms hematopoietic stem cells $(\mathrm{CSH})$ in leukemic stem cells (LSC), inducing the development of chronic stage CML. The symptomatology is explained by the uncontrolled spread of leukemic progenitor cells (LPC). Tyrosine kinase inhibitors (TKIs) such as imatinib, dasatinib and nilotinib, frequently lead to complete cytogenetic responses or major molecular responses, but LSC are intrinsically insensitive to TKIs despite the inhibition of the BCR-ABL1 kinase (CORBIN \& al [44]). Cells in chronic stage CML may acquire epigenetic changes that provide resistance to TKIs and lead to blastic 
transformation (PEROTTI \& al [45]). Genomic instability is one of the distinctive features in a malignantly transformed cell and it provides the basis for BCR-ABL1 mutation development as a long-term effect of TKIs. The endogenous production of ROS is another mechanism of DNA damage. Leukemic cells that express BCR-ABL1 kinase and other oncogenic tyrosine kinases (TEL-ABL1, TEL-JAK2, TEL-PDGFaR, JAK2V617F and FLT3-ITD) accumulate ROS and secondary products formed by the oxidation of DNA constituents, resulting in genomic instability (NOWICKI \& al [46]). It important to establish whether this process starts in the LSC or LPC and to determine the molecular mechanisms involved.

The activity of the BCR-ABL1 oncoprotein was linked to the production of ROS in a convincing manner. The BCR-ABL1 induced by ROS, combined with the reduced capacity to repair the DNA (mainly through RAD51 downregulation), seems to promote genomic instability and, in the end, the "auto-mutagenesis" process. Thus, the development of TKIs resistance becomes possible (KOPTYRA \& al [47]).

Beside the expression of BCR-ABL1, the strong activation of the transcription factor Stat5 is considered a distinctive signaling mechanism in CML cells. The importance of Stat5 in CML pathogenesis is marked out by the fact that Stat5 synthesis increases with disease progression and that the high levels of Stat5 significantly reduce the sensitivity to imatinib. A significant correlation between the level of Stat 5 synthesis and the frequency of BCR-ABL1 mutations in patients with CML was proved. Stat5 initiates the production of ROS and thus induces DNA damage. Simultaneously, Stat5 allows the cells to survive and induces the development of BCR-ABL1 mutations through the positive regulation of anti-apoptotic genes (WARSCH \& al [48]).

It has also been discovered that the "most primitive" LSC in chronic stage CML, including dormant cells and LPC, contain high levels of ROS and DNA damage compared to their healthy counterparts (NIEBOROWSKA $\&$ al [49]). Hence, it has been considered that the genomic instability initiated by ROS in chronic stage CML may even start in the LSC and continue in the LPC. This aspect is sustained by the observations regarding the BCR-ABL1 kinase mutations that cause resistance to TKIs, which were identified in the CD34+ CD38- and CD34+ CD38+ chronic stage CML cells (SOREL \& al [50]). Leukemic cells can tolerate DNA damage due to their antiapoptotic protection and/or by modulating the response to BCR-ABL1mediated DNA damage (SKORSKI [51]).

Genomic instability in LSC and LPC resistant to TKIs is a major concern because these cells are not eliminated through TKIs therapy. Patients with chronic stage CML had $5 \times 10^{7} \mathrm{CD} 34+$ cells with innate resistance to imatinib at the time of diagnosis. Even patients with complete cytogenetic or major molecular response, i.e. BCR-ABL1 through PCR after treatment with imatinib, may have BCR$\mathrm{ABL}^{+}$cells in the CD34+ CD38- compartment. Most of them belong to the TKIs-resistant and/or TKI - refractory LSC population. Genomic instability may be potentiated in these cells, mainly in patients treated with TKIs (CHU \& al [52]).

Idle state LSC seem to have higher levels of ROS and oxidized DNA than the population of proliferative cells, mainly consisting in LPC. Nevertheless, the accumulation of damaged DNA induced by ROS in LPC, mostly in cells that contain TKIs resistance mutations, should not be underestimated. Genomic instability combined with epigenetic changes can lead to the transformation into a more aggressive clone, as it was reported in blastic stage CML (JAMIESON \& al [53]).

MRC-cIII is considered the main ROS source, causing oxidative damage of the DNA in LSC and LPC (NIEBOROWSKA \& al [49]). This effect probably derives from an altered electron transfer between the MRC I-III and II-III complexes which enables electron flows and ROS production (HAN \& al [54]). The continuous increase in ROS levels may depolarize the mitochondrial membrane, leading to the production/release of the pro-apoptotic c-cytochrome. Leukemic cells can compensate the deficit of mitochondrial ATP by increasing glucose absorption and enhancing aerobic glycolysis, while the pro-apoptotic c-cytochrome can be counteracted by the antiapoptotic activity of BCR-ABL1 (BARNES \& al [55]).

$\mathrm{PI} 3 \mathrm{~K}$ seems to enable the production of ROS in BCRABL1+ leukemic cells (KIM \& al [56]). Rac was found not only to interact with p210 BCR-ABL1, but also to create a positive feedback loop with PI3K (HARNOIS \& al [57]), having a major role in producing ROS in CML. Specifically, a Rac2-GTP-dependent mechanism changes the electron flow through MRC, resulting in an overproduction of $\mathrm{O}_{2}$ via MRC-cIII, which consequently leads to DNA damage and genomic instability in LSC and LPC. Moreover, cells from chronic stage CML, i.e. CD34+CD38-, can spread in the presence of imatinib and acquire mutations of the BCRABL1 kinase which can lead to resistance to TKIs and additional chromosome abnormalities (JIANG \& al [58]). Consequently, the Rac2-MRC-cIII pathway can enable ROS-induced DNA oxidation and genomic instability not only in LSC treated with imatinib and/or in LPC that contain mutant BCR-ABL1 resistant to TKIs, but also in LSC and/or LPC that show a significant inhibition of BCR-ABL1 kinase (CORBIN \& al [59]).

Another mechanism of resistance development to TKIs therapy in CML proven in various studies, but still not sufficiently approached, is the BCR-ABL-independent mechanism, linked to an increase in $\mathrm{OxS}$ levels (MITCHELL \& al [60]).

\section{New perspectives in the treatment of CML}

Large scale studies proved that ROS were vital for the normal functioning of cells; likewise, they proved that a high level of OxS might lead to important cell changes that generate cell lesions, malignant transformation, apoptosis etc. It is certain that the limit between the physiological level of OxS and the pathological one is yet unknown, and for this very reason future research endeavors are needed.

Taking into consideration the challenges encountered in the management of this disease, CML remains a research 
topic of great importance in the field of hematology and pathophysiology. New therapeutic strategies which should target exclusively malignant cells, are necessary for this challenging clinical entity in which drug efficiency seems to fade due to the development of TKIs resistance.

Up to the present moment, the antioxidant and prooxidant actions of various standard therapies against leukemia are known, but it remains an important challenge the way in which the RedOx state of cells is influenced during treatment. Also, it is important to prove whether certain additional therapies based on OxS modulation are efficient to prevent genomic instability and disease progression.

Furthermore, the effects of several chemotherapeutic agents are known to be totally or partially based on oxidation-dependent mechanisms. It would be interesting to unravel whether the efficiency of such agents depends on the basal ROS production in malignant cells population or on exogenous sources of ROS.

\section{References}

1. T.H. TRUONG, K.S. CARROLL, Redox Regulation of Protein Kinases. Crit. Rev. Biochem. Mol. Biol., 48(4), 332-356 (2013).

2. G.S. SHADEL, T.L. HORVATH, Mitochondrial ROS Signaling in Organismal Homeostasis. Cell, 163(3), 560-569 (2015).

3. S-A. MANEA, A. CONSTANTIN, G. MANDA, S. SASSON, A. MANEA, Regulation of Nox enzymes expression in vascular pathophysiology: Focusing on transcription factors and epigenetic mechanisms. Redox Biol., 5, 358-366 (2015).

4. J.D. LAMBETH, T. KAWAHARA, B. DIEBOLD, Regulation of Nox and Duox enzymatic activity and expression. Free. Radic. Biol. Med., 43(3), 319-331 (2007).

5. P.S. HOLE, L. PEARN, A. J. TONKS, P.E. JAMES, A.K. BURNETT, R.L. DARLEY, A. TONKS, Ras-induced reactive oxygen species promote growth factor-independent proliferation in human CD34+ hematopoietic progenitor cells. Blood, 115(6), 12381246 (2009).

6. M. KINDER, C. WEI, S.G. SHELAT, M. KUNDU, L. ZHAO, I.A. BLAIR, E. PURE, Hematopoietic stem cell function requires 12/15-lipoxygenasedependent fatty acid metabolism. Blood, 115(24), 5012-5022 (2010).

7. I.N. SHOKOLENKO, G.L. WILSON, M.F. ALEXEYEV, Aging: A mitochondrial DNA perspective, critical analysis and an update. World. J. Exp. Med., 4(4), 46-57 (2014).

8. I. MARROCCO, F. ALTIERI, I. PELUSO, Measurement and Clinical Significance of Biomarkers of Oxidative Stress in Humans. Oxid. Med. Cell. Longev., 2017:6501046, 1-32 (2017).

9. E.B. KURUTAS, The importance of antioxidants which play the role in cellular response against oxidative/nitrosative stress: current state. Nutr. J., 15(1), 71 (2016)

10. D-S STEF, I. GERGEN, T-I TRASCA, A. RIVIS, L. STEF, R. CRISTINA, M. DRUGA, P. IOAN, Assessing the influence of various factors an antioxidant capacity of medicinal herbs. Romanian Biotechnological Letters, 22(4), 12842 (2017)

11. X.G. LEI, J.H. ZHU, W.H. CHENG, Y. BAO, Y.S. HO, A.R. REDDI, A. HOLMGREN, E.S. ARNÉR, Paradoxical Roles of Antioxidant Enzymes: Basic Mechanisms and Health Implications. Physiol. Rev., 96(1), 307-364 (2016).

12. R. ANU, K. AMIT, S. VIVEK, Y. BRIJESH, T. RUCHI, C. SANDIP, D. KULDEEP, Oxidative Stress, Prooxidants, and Antioxidants: The Interplay. Biomed. Res. Int., 2014 (2014):761264, 1-19 (2014).

13. Y. IKEBUCHI, N. MASUMOTO, K. TASAKAT, K. KOIKE, K. KASAHARA, A. MIYAKE, O. TANIZAWA, Superoxide anion increases intracellular $\mathrm{pH}$, intracellular free calcium, and arachidonate release in human amnion cells. J. Biol. Chem., 266(20), 13233-13237 (1991).

14. Q.S. ZHU, L. XIA, G.B. MILLS, C.A. LOWELL, I.P. TOUW, S.J. COREY, G-CSF induced reactive oxygen species involves Lyn-PI3-kinase-Akt and contributes to myeloid cell growth. Blood, 107(5), 1847-1856 (2006).

15. H. SIES, Hydrogen peroxide as a central redox signaling molecule in physiological oxidative stress: oxidative eustress. Redox. Biol., 11(2017), 613-619 (2017).

16. M. ABDOUH, R. HANNA, J. EL HAJJAR, A. FLAMIER, G. BERNIER, The Polycomb Repressive Complex 1 Protein BMI1 Is Required for Constitutive Heterochromatin Formation and Silencing in Mammalian Somatic Cells. J. Biol. Chem., 291(1), 182-197 (2016).

17. S. YALCIN, D. MARINKOVIC, S.K. MUNGAMURI, X. ZHANG, W. TONG, R. SELLERS, S. GHAFFARI, ROS-mediated amplification of AKT/mTOR signalling pathway leads to myeloproliferative syndrome in Foxo3(-/-) mice. EMBO J., 29(24), 4118-4131 (2010).

18. A. JOSHI, M. KUNDU, Mitophagy in hematopoietic stem cells: The case for exploration. Autophagy, 9(11), 1737-1749 (2013).

19. Z. TOTHOVA, R. KOLLIPARA, B.J. HUNTLY, B. H. LEE, D.H. CASTRILLON, D.E. CULLEN, E.P. MCDOWELL, S. LAZO-KALLANIAN, I.R. WILLIAMS, C. SEARS, S.A. ARMSTRONG, E. PASSEGUÉ, R.A. DEPINHO, D.G. GILLILAND, FoxOs are critical mediators of hematopoietic stem cell resistance to physiologic oxidative stress. Cell, 128(2), 325-339 (2007).

20. T. SUDA, K. TAKUBO, G. L. SEMENZA, Metabolic Regulation of Hematopoietic Stem Cells in the Hypoxic Niche. Cell. Stem. Cell., 9(4), 298-310 (2011).

21. D. LEWANDOWSKI, V. BARROCA, F. DUCONGE, J. BAYER, J.T. VAN NHIEU, C. PESTOURIE, 
P. FOUCHET, B. TAVITIAN, P. H. ROMÉO, In vivo cellular imaging pinpoints the role of reactive oxygen species in the early steps of adult hematopoietic reconstitution. Blood, 115(3), 443- 452 (2010).

22. M. USHIO-FUKAI, N. URAO, Novel Role of NADPH Oxidase in Angiogenesis and Stem/Progenitor Cell Function. Antioxid. Redox Signal., 11(10), 2517-2533 (2009).

23. K. GOLAN, Y. VAGIMA, A. LUDIN, T. ITKIN, S. COHEN-GUR, A. KALINKOVICH, O. KOLLET, C. KIM, A. SCHAJNOVITZ, Y. OVADYA, K. LAPID, S. SHIVTIEL, A.J. MORRIS, M.Z. RATAJCZAK, T. LAPIDOT, S1P promotes murine progenitor cell egress and mobilization via S1P1-mediated ROS signaling and SDF-1 release. Blood, 119(11), 24782488 (2012).

24. J.H. KIM, S.C. CHU, J.L. GRAMLICH, Y.B. PRIDE, E. BABENDREIER, D. CHAUHAN, R. SALGIA, K. PODAR, J.D. GRIFFIN, M. SATTLER, Activation of the PI3K/mTOR pathway by BCR$\mathrm{ABL}$ contributes to increased production of reactive oxygen species. Blood, 105(4), 1717-1723 (2005).

25. M.S. RODRIGUES, M.M. REDDY, M. SATTLER, Cell cycle regulation by oncogenic tyrosine kinases in myeloid neoplasias: from molecular redox mechanisms to health implications. Antioxid. Redox Signal., 10(10), 1813-1848 (2008).

26. M.E. IRWIN, B.P. JOHNSON, R. MANSHOURI, H.M. AMIN, J.A. CHANDRA, NOX2/Egr-1/Fyn pathway delineates new targets for TKI-resistant malignancies. Oncotarget, 6(27), 23631-23646 (2015).

27. F.V. RASSOOL, T.J. GAYMES, N. OMIDVAR, N. BRADY, S. BEURLET, M. PLA, M. REBOUL, N. LEA, C. CHOMIENNE, N.S. THOMAS, G.J. MUFTI, R.A. PADUA, Reactive oxygen species, DNA damage, and errorprone repair: a model for genomic instability with progression in myeloid leukemia?. Cancer Res., 67(18), 8762-8771 (2007).

28. T.K. ER, S.M. TSAI, S.H. WU, W. CHIANG, H.C. LIN, S.F. LIN, S.H. WU, L.Y. TSAI, T.Z. LIU, Antioxidant status and superoxide anion radical generation in acute myeloid leukemia. Clin. Biochem., 40(13-14), 1015-1019 (2007).

29. A. ABDUL-AZIZ, D.J. MACEWAN, K.M. BOWLES, S.A. RUSHWORTH, Oxidative Stress Responses and NRF2 in Human Leukaemia. Oxid. Med. Cell. Longev., 2015(2015), 454659, 1-7 (2015).

30. P.S. WARD, J. PATEL, D.R. WISE, O. ABDELWAHAB, B.D. BENNETT, H.A. COLLER, J.R. CROSS, V.R. FANTIN, C.V. HEDVAT, A.E. PERL, J.D. RABINOWITZ, M. CARROLL, S.M. SU, K.A. SHARP, R.L. LEVINE, C.B. THOMPSON, The common feature of leukemia-associated IDH1 and IDH2 mutations is a neomorphic enzyme activity converting alpha-ketoglutarate to 2-hydroxyglutarate. Cancer Cell, 17(3), 225-234 (2010).

31. A.M. GĂMAN, A.M. BUGĂ, M.-A. GĂMAN, A. POPA-WAGNER, The Role of Oxidative Stress and the Effects of Antioxidants on the Incidence of
Infectious Complications of Chronic Lymphocytic Leukemia. Oxid. Med. Cell. Longev., 2014 (2014): 158135, 1-6 (2014).

32. M.-A. GĂMAN, E.G. PASCU, A.M. GĂMAN, The Evaluation of the Total Antioxidant Capacity in Relation to the Treatment with Tyrosine-Kinase Inhibitors in Chronic Myeloid Leukemia. HemaSphere, 2(S1), 891-891 (2018).

33. U.K. UDENSI, P.B. TCHOUNWOU, Dual effect of oxidative stress on leukemia cancer induction and treatment. J. Exp. Clin. Cancer Res., 33(106), 1-15 (2014).

34. J. STANICKA, E.G. RUSSELL, J.F. WOOLLEY, T.G. COTTER, NADPH Oxidase-generated Hydrogen Peroxide Induces DNA Damage in Mutant FLT3expressing Leukemia Cells. J. Biol. Chem., 290(15), 9348-9361 (2015).

35. A. SALLMYR, J. FAN, K. DATTA, K.T. KIM, D. GROSU, P. SHAPIRO, D. SMALL, F. RASSOOL, Internal tandem duplication of FLT3 (FLT3/ITD) induces increased ROS production, DNA damage, and misrepair: implications for poor prognosis in AML. Blood, 111(6), 3173-3182 (2008).

36. M. COBBAUT, J. VAN LINT, Function and Regulation of Protein Kinase D in Oxidative Stress: A Tale of Isoforms. Oxid. Med. Cell. Longev., 2018(2018): 2138502, 1-10 (2018).

37. Y. GAO, A. HOWARD, K. BAN, J. CHANDRA, Oxidative stress promotes transcriptional up-regulation of Fyn in BCR-ABL1-expressing cells. J. Biol. Chem., 284(11), 7114-7125 (2009).

38. S.A. SINENKO, T. HUNG, T. MOROZ, Q.M. TRAN, S. SIDHU, M.D. CHENEY, N.A. SPECK, U. BANERJEE, Genetic manipulation of AML1-ETOinduced expansion of hematopoietic precursors in a Drosophila model. Blood, 116(22), 4612-4620 (2010).

39. T. MARALDI, C. PRATA, D. FIORENTINI, L. ZAMBONIN, L. LANDI, G. HAKIM, Induction of apoptosis in a human leukemic cell line via reactive oxygen species modulation by antioxidants. Free Radic. Biol. Med., 46(2), 244-252 (2009).

40. A. M. GĂMAN, A. UZONI, A. POPA-WAGNER, A. ANDREI, E.-B. PETCU, The Role of Oxidative Stress in Etiopathogenesis of Chemotherapy Induced Cognitive Impairment (CICI)-"Chemobrain". Aging Dis., 7(3), 307-317 (2016).

41. P.D. COLE, Y. FINKELSTEIN, K.E. STEVENSON, T.M. BLONQUIST, V. VIJAYANATHAN, L.B. SILVERMAN, D.S. NEUBERG, S.E. SALLAN, P. ROBAEY, D.P. WABER, Polymorphisms in Genes Related to Oxidative Stress Are Associated With Inferior Cognitive Function After Therapy for Childhood Acute Lymphoblastic Leukemia. J. Clin. Oncol., 33(19), 2205-2211 (2015).

42. C. DIACONU, C. MAMBET, L. NECULA, P. GURBAN, L. MATEI, I. ALDEA-PITICA, A. BOTEZATU, C. BLEOTU, M. CHIVUECONOMESCU, V. ROMAN, D. CORIU, S. CONSTANTINESCU, Triple negative myeloprolife- 
rative neoplasms - sometimes driver mutations stay low-key in plain sight. Romanian Biotechnological Letters, 23 (4), 13750-13760 (2018).

43. J.V. MELO, D.J. BARNES. Chronic myeloid leukaemia as a model of disease evolution in human cancer. Nat. Rev. Cancer, 7(6), 441-453 (2007).

44. A.S. CORBIN, A. AGARWAL, M. LORIAUX, J. CORTES, M.W. DEININGER, B.J. DRUKER, Human chronic myeloid leukemia stem cells are insensitive to imatinib despite inhibition of BCRABL activity. J. Clin. Invest., 121(1), 396-409 (2011).

45. D. PERROTTI, C. JAMIESON, J. GOLDMAN, T. SKORSKI, Chronic myeloid leukemia: mechanisms of blastic transformation. J. Clin. Invest., 120(7), 2254-2264 (2010).

46. M.O. NOWICKI, R. FALINSKI, M. KOPTYRA, A. SLUPIANEK, T. STOKLOSA, E. GLOC, M. NIEBOROWSKA-SKORSKA, J. BLASIAK, T. SKORSKI, BCR/ABL oncogenic kinase promotes unfaithful repair of the reactive oxygen speciesdependent DNA double-strand breaks. Blood, 104(12), 3746-3753 (2004).

47. M. KOPTYRA, R. FALINSKI, M.O. NOWICKI, T. STOKLOSA, I. MAJSTEREK, M. NIEBOROWSKASKORSKA, J. BLASIAK, T. SKORSKI, BCR/ABL kinase induces self-mutagenesis via reactive oxygen species to encode imatinib resistance. Blood, 108(1), 319-327 (2006).

48. W. WARSCH, E. GRUNDSCHOBER, A. BERGER, L. GILLE, S. CERNY-REITERER, A.S. TIGAN, A. HOELBL-KOVACIC, P. VALENT, R. MORIGGL, V. SEXL, STAT5 triggers BCR-ABL1 mutation by mediating ROS production in chronic myeloid leukaemia. Oncotarget, 3(12), 1669-87 (2012).

49. M. NIEBOROWSKA-SKORSKA, P.K. KOPINSKI, R. RAY, G. HOSER, D. NGABA, S. FLIS, K. CRAMER, M.M. REDDY, M. KOPTYRA, T. PENSERGA, E. GLODKOWSKA-MROWKA, E. BOLTON, T.L. HOLYOAKE, C.J. EAVES, S CERNY-REITERER, P. VALENT, A. HOCHHAUS, T. P. HUGHES, H. VAN DER KUIP, M. SATTLER, W. WIKTOR-JEDRZEJCZAK, C. RICHARDSON, A. DORRANCE, T. STOKLOSA, D.A. WILLIAMS, T. SKORSKI, Rac2-MRC-cIII-generated ROS cause genomic instability in chronic myeloid leukemia stem cells and primitive progenitors. Blood, 119(18), 4253-4263 (2012).

50. N. SOREL, M.L. BONNET, M. GUILLIER, F. GUILHOT, A. BRIZARD, A.G. TURHAN, Evidence of ABL-kinase domain mutations in highly purified primitive stem cell populations of patients with chronic myelogenous leukemia. Biochem. Biophys. Res. Commun., 323(3), 728-730 (2004).
51. T. SKORSKI, Oncogenic tyrosine kinases and the DNA-damage response. Nat. Rev. Cancer, 2(5), 351360 (2002).

52. S. CHU, T. MCDONALD, A. LIN, S. CHAKRABORTY, Q. HUANG, D.S. SNYDER, R. BHATIA, Persistence of leukemia stem cells in chronic myelogenous leukemia patients in prolonged remission with imatinib treatment. Blood, 118(20), 5565-5572 (2011).

53. C.H. JAMIESON, L.E. AILLES, S.J. DYLLA, M. MUIJTJENS, C. JONES, J.L. ZEHNDER, J. GOTLIB, K. LI, M. G. MANZ, A. KEATING, C.L. SAWYERS, I.L. WEISSMAN, Granulocyte-macrophage progenitors as candidate leukemic stem cells in blast-crisis CML. N. Engl. J. Med., 351(7), 657-667 (2004).

54. F. HAN, T. DA, N.A. RIOBO, L.B. BECKER, Early mitochondrial dysfunction in electron transfer activity and reactive oxygen species generation after cardiac arrest. Crit. Care Med., 36(11 suppl), S447-S453 (2008).

55. K. BARNES, E. MCINTOSH, A.D. WHETTON, G.Q. DALEY, J. BENTLEY, S.A. BALDWIN, Chronic myeloid leukaemia: an investigation into the role of Bcr-Abl-induced abnormalities in glucose transport regulation. Oncogene, 24(20), 3257-3267 (2005).

56. J.H. KIM, S.C. CHU, J.L. GRAMLICH, Y.B. PRIDE, E. BABENDREIER, D. CHAUHAN, R. SALGIA, K. PODAR, J. D. GRIFFIN, M. SATTLER, Activation of the PI3K/mTOR pathway by BCR-ABL contributes to increased production of reactive oxygen species. Blood, 105(4), 1717-1723 (2005).

57. T. HARNOIS, B. CONSTANTIN, A. RIOUX, E. GRENIOUX, A. KITZIS, N. BOURMEYSTER, Differential interaction and activation of Rho family GTPases by p210bcr-abl and p190bcr-abl. Oncogene, 22(41), 6445-6454 (2003).

58. X. JIANG, K.M. SAW, A. EAVES, C. EAVES, Instability of BCR-ABL gene in primary and cultured chronic myeloid leukemia stem cells. J. Natl. Cancer Inst., 99(9), 680-693 (2007).

59. A.S. CORBIN, A. AGARWAL, M. LORIAUX, J. CORTES, M.W. DEININGER, B.J. DRUKER, Human chronic myeloid leukemia stem cells are insensitive to imatinib despite inhibition of BCR-ABL activity. J. Clin. Invest., 121(1), 396-409 (2011).

60. R. MITCHELL, L.E. M. HOPCROFT, P. BAQUERO, E.K. ALLAN, K. HEWIT, D. JAMES, G. HAMILTON, A. MUKHOPADHYAY, J. O'PREY, A. HAIR, J.V. MELO, E. CHAN, K.M. RYAN, V. MAGUERSATTA, B.J. DRUKER, R.E. CLARK, S. MITRA, P. HERZYK, F.E. NICOLINI, P. SALOMONI, E. SHANKS, B. CALABRETTA, T.L. HOLYOAKE, G.V. HELGASON, Targeting BCR-ABL-Independent TKI Resistance in Chronic Myeloid Leukemia by mTOR and Autophagy Inhibition. J. Natl. Cancer Inst., 110(5), 467-478 (2018). 